\title{
Environmental Drivers on Green Supply Chain Practices
}

\author{
Padmalalitha T V, TR Rajeswari \\ Department of Management and Commerce, Sri Sathya Sai Institute of Higher Learning, Anantapur - 515001, India
}

\section{ARTICLE INFO}

Keywords:

Environmental Concern,

Business Anxiety,

Corporate Environmental Drivers,

Green Supply Chain Practices,

Structural Equation Model,

Path Analysis

\section{Kata Kunci:}

Kepedulian Lingkungan,

Kecemasan Bisnis,

Penggerak Lingkungan Perusahaan,

Praktik Rantai Pasok Hijau,

Model Structural Equation,

Path Analysis

\section{A B S T R A C T}

Environmental concern is one of the linchpins of business anxieties since post-industrial era in India. In the current scenario where the corporates in India are committing to green supply chain practices, this paper attempts to understand the key environmental drivers that impact green supply chain practices. Thus, the focus of this research paper is to recognize the direct and indirect effects of environmental drivers on the green supply chain practices. Quantitative data regarding corporate environmental drivers and green supply chain practices were collected from 12 manufacturing companies in India. Path analysis was performed through structural equation modeling technique to identify the significant environmental drivers. Further, the direct and indirect effects of the environmental drivers were determined by decomposing the structural equations. The results obtained demonstrated that regulatory pressure, customer pressure, socio-cultural pressure and competitor pressure affect green supply chain practices at varying levels of significance at different stages of the supply chain process. The result of this study invites necessary attention of the managers to undertake an analysis of the effect of potential environmental drivers on the functioning of green supply chain practices in their firms.

SARI PATI

Kepedulian lingkungan merupakan salah satu inti keresahan bisnis sejak era pascaindustri di India. Dalam skenario terkini atas perusahaan di India yang berkomitmen pada praktik rantai pasok ramah lingkungan, makalah ini mencoba memahami pendorong utama bidang lingkungan yang memengaruhi praktik rantai pasokan hijau. Dengan demikian, fokus makalah penelitian ini adalah mengenali efek langsung dan tidak langsung dari pendorong lingkungan pada praktik rantai pasok hijau. Data kuantitatif mengenai penggerak lingkungan perusahaan dan praktik rantai pasok hijau dikumpulkan dari 12 perusahaan manufaktur di India. Analisis jalur dilakukan melalui teknik pemodelan persamaan struktural untuk mengidentifikasi pendorong lingkungan yang signifikan. Selanjutnya, efek langsung dan tidak langsung dari faktor pendorong lingkungan ditentukan dengan menguraikan persamaan struktural. Hasil menunjukkan bahwa tekanan regulasi, tekanan pelanggan, tekanan sosio-budaya, dan tekanan 
pesaing memengaruhi praktik rantai pasok hijau pada berbagai tingkat secara signifikan, dan pada berbagai tahap proses rantai pasok. Hasil dari penelitian ini memberikan perhatian yang perlu dari para manajer untuk melakukan analisis tentang pengaruh pendorong lingkungan potensial terhadap berfungsinya praktik rantai pasok hijau di perusahaan mereka.

(C) 2020 IRJBS, All rights reserved.

\section{INTRODUCTION}

The Indian corporates are currently operating in an era of a paradigm shift. The environmental issues have invited the necessary attention of the corporates to check their work practices and strategies. In reality, the journey towards greening the corporate practices is challenging, specially to capture the social and environmental benefits. More of a genuine concern than just a concept, interlacing green practices with business strategies has become the current business scenario with win-win potentials for business success and sustainable environmental practices. In alignment with this idea, Green Supply Chain Management (GSCM) has developed to integrate green practices with the traditional supply chain functions. This integration brings a start-to-end management of the supply chain starting from suppliers, through manufacturers and distributors, to the final customers. Undeniably, the main motivation of adopting GSCM by the organisations is to mitigate environmental degradation, and enhance environmental and economic performance.

In emerging economies like India, where environmental health and ecosystem vitality is observed to be poor, multiple Corporate Environmental Drivers (CED) induct the corporate practices towards GSCM. The CEDs move the motivation behind the 'triple supply chain advantage', thus facilitating the corporates to achieve profitability, upsurge environmental health, and witness societal benefits through GSCM.
In the current scenario where the corporates are committing to green thinking, this paper attempts to understand the key environmental drivers that affect GSCM practices. Thus, the objectives of this research paper are:

1. To understand the direct effect of the CEDs on the GSCM practices

2. To derive the indirect effect of the CEDs on GSCM practices, because of the association of one CED on the other and hence to assess the cumulative effect of the drivers

The subsequent sections of this paper are ordered as follows. First, through literature review, various indicators of GSCM practices, and the potential drivers of CEDs are recognized to identify the research gap. Second, the data collected from 220 respondents of 12 manufacturing organisations are analyzed using Structural Equation Model (SEM) and path analysis. Third, the insights derived from the data analysis are discussed. The last section of the paper presents the concluding remarks, implications, limitations and scope for further research.

\section{LITERATURE REVIEW}

This section is presented to categorize the variables associated with GSCM and CED, and to understand the gap in literature with respect to CED and GSCM.

\section{Green Supply Chain Practices}

"Green Procurement (GP), Green Manufacturing (GM), Green Distribution (GD), and Reverse Logistics (RL) define major environmentally conscious, operational elements of an organization 
by integrating environmental concerns in supply chain practices" (Preuss, 2005). Supply chain integrates the functional arena among the supplier, manufacturer, distributor and customer, and facilitates a closed loop (Zhu et al., 2005; CheckTeck, 2010). The GSCM practices promote efficiency and help achieve enhanced environmental performance (Rao \& Holt, 2005). GSCM not only minimizes negative environmental impact but also contributes to the firm's cost benefits (Zhu et al., 2010). GSCM presents opportunities to establish reactive monitoring practices to be proactive in implementing green practices as a part of an organization's environmental program (Sarkis, 2012).

GSCM practices are grounded in the claim of High Reliability theory - "to emerge as reliable firms, organisational remedies like agility and adaptive capability are applied in the supply chain practices to deal with interactive complexities in the organization" (Beyea, 2005). The organisation's approach to GSCM help environmental experts to formulate strategies, and achieve effectiveness in the environmental programs (Bag, 2013). GSCM demonstrates inter-organisational relationships with the supplier firms and supports the claim of Resource Dependency theory that "no organization is self-sufficient in itself" (Gerlagh \& Liski, 2011; Bag, 2013). Thus, GSCM gears "cross-functional cooperation and communication in an organization facilitating collaboration and environmental improvements" (Vivek at al., 2009; Verma et al., 2018).

To draw an understanding of the indicators of associated variables of GSCM practices, methodical search and systematic review of research papers which were within the focus of the current study was undertaken. The GSCM variables representing various indicators from previous research studies are summarized in Table 1.

Table 1. Indicators of the Variables Associated with GSCM

\begin{tabular}{|c|c|c|c|}
\hline Source & \multicolumn{2}{|c|}{ Identified Indicators } & $\begin{array}{c}\text { Associated GSCM } \\
\text { Practices } \\
\end{array}$ \\
\hline \multirow{2}{*}{ (Martí \& Seifert, 2013) } & \multicolumn{2}{|c|}{ Eco-Design Specification of Suppliers } & $\begin{array}{l}\text { Green } \\
\text { Procurement }\end{array}$ \\
\hline & \multicolumn{2}{|c|}{ ISO 14001 Certification of Suppliers } & \\
\hline $\begin{array}{l}\text { (Bag, 2013; Morana \& Morana, } \\
\text { 2013) }\end{array}$ & Eco-design Specifications & \multirow{2}{*}{$\begin{array}{l}\text { Product } \\
\text { Design and } \\
\text { Development }\end{array}$} & \multirow{6}{*}{$\begin{array}{l}\text { Green } \\
\text { Manufacturing }\end{array}$} \\
\hline (Gunningham, 2009) & Life Cycle Assessment & & \\
\hline (Huang \& Chu, 2010) & $\begin{array}{l}\text { Top Management } \\
\text { Commitment }\end{array}$ & \multirow{4}{*}{$\begin{array}{l}\text { Internal } \\
\text { Environmental } \\
\text { Management }\end{array}$} & \\
\hline $\begin{array}{l}\text { (Khare \& Khare, 2010; Swami \& } \\
\text { Shah, 2013) }\end{array}$ & $\begin{array}{l}\text { Cross Functional } \\
\text { Cooperation }\end{array}$ & & \\
\hline $\begin{array}{l}\text { (Walker et al., 2007; Fox et } \\
\text { al., 2009; Miler-Virc \& Glusica, } \\
\text { 2012) }\end{array}$ & $\begin{array}{l}\text { Environmental } \\
\text { Management System }\end{array}$ & & \\
\hline $\begin{array}{l}\text { (Edser, 2009; Onozaka et al., } \\
2015 \text { ) }\end{array}$ & Eco-Labelling & & \\
\hline \multirow{2}{*}{$\begin{array}{l}\text { (Sanjeev Swami \& Shah, 2011; } \\
\text { Cai, 2012; Ouyang, 2014) }\end{array}$} & \multicolumn{2}{|l|}{ Green Packaging } & \multirow{2}{*}{ Green Distribution } \\
\hline & Green Logistics & & \\
\hline \multirow{2}{*}{$\begin{array}{l}\text { (Srivastava, 2004; Morgan et al., } \\
\text { 2016) }\end{array}$} & \multicolumn{2}{|l|}{ Used Product Recovery } & \multirow{2}{*}{ Reverse Logistics } \\
\hline & \multicolumn{2}{|c|}{ Disassembly / Recycle Plant Facilities } & \\
\hline
\end{tabular}

Source: Compiled by the Author 


\section{Corporate Environmental Drivers}

Adoption of green practices in the organisation arises due to environmental drivers (Sharma, 2001). The corporate environmental drivers surge "coercive, mimetic and normative" pressures that necessitate firms to adopt green practices in the organisation (Sanjeev Swami \& Shah, 2011). Coercive isomorphic change in the organisation is mainly driven through government mandates and cultural expectations from the society (Tachizawa et al., 2015). Mimetic isomorphic change in the organisation is mainly caused by the tendency to adopt green practices from the industry peers for the sustenance of the firm in the industry (Colwell \& Joshi, 2009; Fu et al., 2018). Normative isomorphic changes in the organisation are driven by societal expectations, customer expectations and the work pressure from the environment in which the industry operates (Colwell \& Joshi, 2009). Institutional theory viewpoint posits that customer pressure and regulatory pressure are influential for firms to promote GSCM practices (Raak et al., 2005; Suddaby, 2010). From the systems theory perspective, the organisations operate in a systemic, integrative and inclusive environment where customers and industry drive the operational practices of the firm towards green practices (Caddy \& Helou, 2007). From the socio-cultural theory viewpoint, the organisation's external and internal processes are based on the belief system and organisational image (Diabat et al., 2014). Thus, the major corporate environmental drivers of GSCM practices include regulatory pressures, customer pressures, socio-cultural pressures and competitor pressures.

\section{Corporate Environmental Drivers and Green Supply} Chain Management Practices - Gap Identification

The environmental drivers with respect to supply chain were studied by researchers to understand about the management approach towards GSCM practices and performance implications (Tachizawa et al., 2015), to explore the factors that drive or hinder the GSCM pactices (H. Walker et al., 2008; Setthasakko, 2009; Rauer \& Kaufmann, 2014; Faisal,
2015; Dhull \& Narwal, 2016) and to compare the pressures on GSCM practices in various industries like hotel (Shah, 2011), and pharmaceutical (Faisal, 2015).

In the Indian context, previous studies attempt to draw the contextual relationship between the drivers and GSCM practices through interpretive structural modelling (Diabat \& Govindan, 2011), understand the essential drivers for implementation of GSCM through the analytic hierarchy processing (Mathiyazhagan et al., 2013) and analyse the variance of pressures in various industries using ANOVA (Xu et al., 2013).

It was observed that the studies undertaken so far have concentrated only on single consensus model approach for analysis and hence, this study deploys plural and dynamic models in order to empirically validate the cumulative impact of the environmental drivers on GSCM practices. Thus, in this study, structural equation model (SEM) technique is used to validate the causal linkage between CED and GSCM, path analysis is carried out to derive an understanding of the direct effect of the CEDs on GSCM and mathematical approach is undertaken to understand the indirect effect of CEDs on GSCM. The understanding of direct and indirect effects of CEDs on GSCM will enable a holistic understanding of the impact of CEDs on GSCM and can expedite appropriate GSCM strategies.

\section{METHODS}

The primary focus of the study is to understand the direct and indirect effects of CEDs on GSCM practices. For the same, causal-comparative research approach was adopted to understand the cause-effect equation between the CEDs and GSCM practices. 12 select companies were chosen based on convenience sampling from the manufacturing sector in India for the study. The respondents of the survey, who were adept in knowledge about the environmental practices of the organisation, were chosen on consultation with the HR executives using convenience sampling technique. Based on 
the variables identified through review of literature, a questionnaire designed. The questionnaire developed comprised of 14 items under GSCM practices and 15 items representing CEDs on a five-point scale, and demographic details included the industry type, company size, department, and work tenure and age of the participants. A summary of the sample respondents is presented in Table 2.

Content validity on the items of the questionnaire is established as the contents were selected after recursive review of literature and the developed questionnaire was approved by industry experts of the sample companies. Initially, pilot study was conducted in all sample companies to validate the constructs of the questionnaire. Statistically, the construct validity was established through confirmatory factor analysis based on a valid sample of 220 responses. TLI $=0.968, \mathrm{CFI}=0.977$ and RMSEA $=0.033$ revealed a satisfactory fit of the constructs. Factor loadings were significant for all the constructs with $\mathrm{p}<0.05$. Cronbach alpha coefficient was computed using SPSS and the reliability value of 0.837 showed acceptable level of internal consistency of the constructs. From the 220 responses collected through the questionnaire, SEM and Path Analysis were performed to understand the direct and indirect effects of CED on GSCM.

\section{ANALYSIS AND RESULTS}

SEM of CED and GSCM was created in Warp PLS 6.0. In the SEM between CED and GSCM, the variables of CED - Regulatory Pressure (RP), Customer Pressure (CuP), Socio-cultural Pressure $(\mathrm{ScP})$ and Competitor Pressure (CoP) are the exogenous variables and the variables of GSCM - Green Procurement (GP), Green Manufacturing (GM), Green Distribution (GD) and Reverse Logistics (RL) are the endogenous variables. For the SEM developed, the structural equation with respect to the exogenous (CED) and endogenous (GSCM) variables are as follows:

$$
\begin{aligned}
& G P=\alpha_{G P}+\beta_{G P, R P} R P+\beta_{G P, C u P} C u P+\beta_{G P, S c P} S c P \\
& +\beta_{G P, C O P} \mathrm{CoP}+e_{G P} \\
& G M=\alpha_{G M}+\beta_{G M, R P} R P+\beta_{G M, C u P} C u P+\beta_{G M, S C P} S c P \\
& +\beta_{G M, C O P} C O P+e_{G M}
\end{aligned}
$$

\begin{tabular}{|c|c|c|}
\hline Sample Characteristics & Sample $(N=220)$ & Percentage \\
\hline \multicolumn{3}{|l|}{ Experience } \\
\hline Less than One year & 19 & 8.6 \\
\hline $2-5$ Years & 40 & 18.2 \\
\hline 6-10 Years & 47 & 21.4 \\
\hline 11-15 Years & 30 & 13.6 \\
\hline 16-20 Years & 34 & 15.5 \\
\hline Over 20 Years & 50 & 22.7 \\
\hline \multicolumn{3}{|l|}{ Age } \\
\hline $18-25$ & 27 & 12.3 \\
\hline $26-33$ & 31 & 14.1 \\
\hline $34-41$ & 48 & 21.8 \\
\hline $42-49$ & 42 & 19.1 \\
\hline $50-55$ & 43 & 19.5 \\
\hline $55+$ & 29 & 13.2 \\
\hline \multicolumn{3}{|l|}{ Industry Type } \\
\hline Automotive Component Manufacturers & 57 & 26.0 \\
\hline Bearings and Castings Manufacturers & 54 & 24.5 \\
\hline Abrasives and Suspension Bush Manufacturers & 63 & 28.6 \\
\hline Pneumatics and Compressors Manufacturers & 46 & 20.9 \\
\hline
\end{tabular}

Table 2. Description of the sample 
$G D=\alpha_{G D}+\beta_{G D, R P} R P+\beta_{G D, C u P} C u P+\beta_{G D, S C P} S c P$

$+\beta_{G D, C o P} \operatorname{CoP}+e_{G D}$

$R L=\alpha_{R L}+\beta_{R L, R P} R P+\beta_{R L, C u P} C u P+\beta_{R L, S C P} S c P$

$+\beta_{R L, C o P} C O P+e_{R L}$

where, $\alpha$ is the constant term, $\beta$ is the path coefficient and $e_{G P}, e_{G M}, e_{G D}, e_{R L}$ are the error terms. The SEM created for the variables of CED and GSCM are shown in the Figure 1.

Model fit indices that are considered to ensure that the model developed is fit are: Average Path Coefficient $=0.174, \mathrm{P}=0.002<0.05 ;$ Average $\mathrm{R}$ Squared $=0.320, \mathrm{P}<0.001 ;$ Average Adjusted $\mathrm{R}$ Squared $=0.308, \mathrm{P}<0.001$; Average Block Variance Inflation Factor $=1.802$; Average Full Collinearity VIF $=2.105$; Tenanhaus GoF $=0.450$; Simpson's Paradox Ratio $=0.813$; R-Squared Contribution Ratio $=0.967 ;$ Statistical Suppression Ratio = 1.000; Nonlinear Bivariate Causality Direction Ratio $=1.000$. Since the calculated values are within the acceptable limit the model is found fit. To understand the influence of the CEDs on GSCM practices, path analysis is carried out from the SEM created.
The path coefficients derived from the path analysis were used in examining the possible causal linkage between the statistical variables in SEM between CED and GSCM. In the developed SEM, for endogenous variables of GSCM, the exogenous variables of CED are depicted as the causes because the variables of CED are causally prior to the variables of GSCM. The path analysis between exogenous and endogenous variables is used to analyze the following:

1. Direct Effect (X impacts Y)

2. Indirect Effect (If $X$ is associated with $Z$ and $Z$ impacts Y, then X impacts Y)

Direct Effect: The path coefficients of the variables of GSCM practices (GP, GM, GD, and RL) and CED (RP, CuP, ScP, and CoP) are used to estimate the significance and magnitude of direct causal connections between the variables of GSCM practices and CED. The path coefficients depicting the direct effects of the variables of CED on GSCM, obtained in the SEM are depicted in Table 3.

From table 3 , it can be inferred that the path coefficients of the variables of GSCM are significant

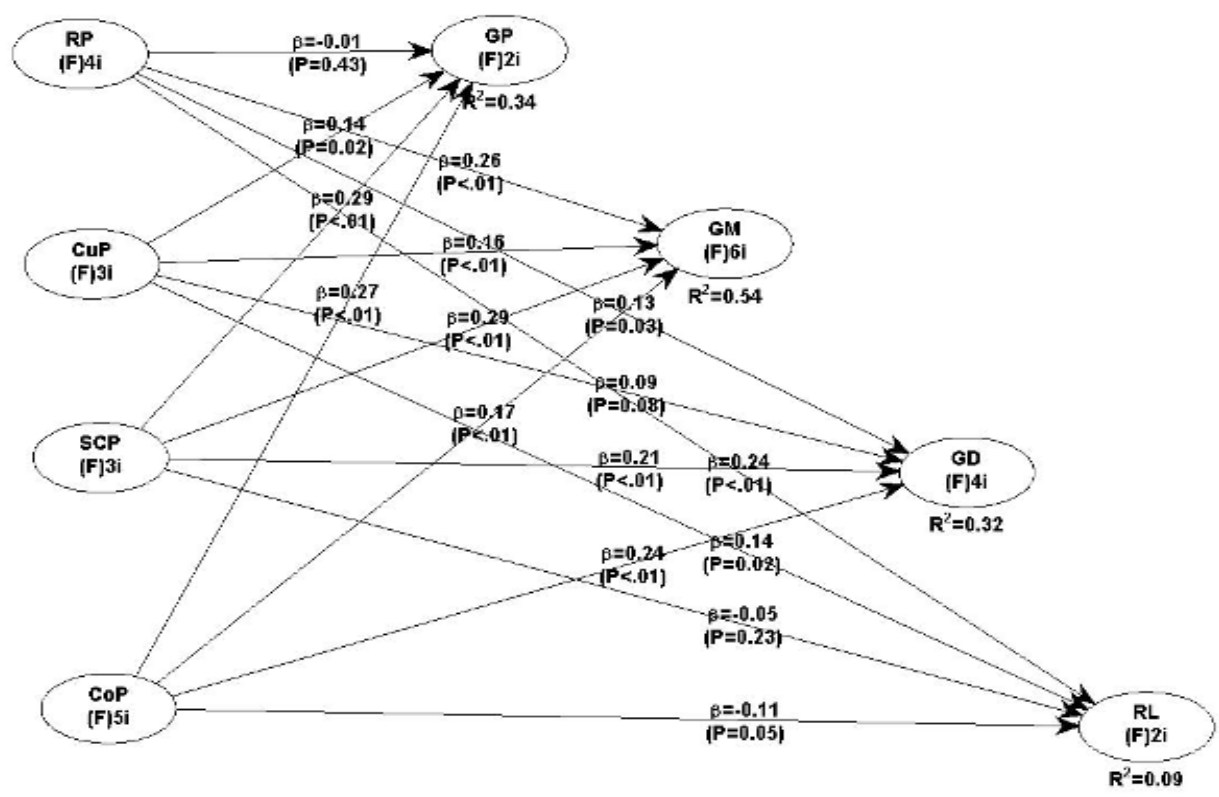

Figure 1. SEM of CED and GSCM

Source: Generated in Warp PLS 6.0 with Primary Data 
Table 3. Direct Effects of CED and GSCM Variables

\begin{tabular}{ccccc}
\hline \multirow{2}{*}{ Variables of CED } & \multicolumn{4}{c}{ Variables of GSCM } \\
\cline { 2 - 5 } & GP & GM & GD & RL \\
\hline RP & -0.011 & $0.258^{* *}$ & $0.125^{*}$ & $0.237^{* *}$ \\
\hline CuP & $0.138^{*}$ & $0.161^{* *}$ & 0.093 & $0.138^{*}$ \\
\hline ScP & $0.286^{* *}$ & $0.286^{* *}$ & $0.214^{* *}$ & -0.049 \\
\hline CoP & $0.266^{* *}$ & $0.169^{* *}$ & $0.242^{* *}$ & $-0.108^{*}$ \\
\hline
\end{tabular}

**p value between 0.000 and 0.010 - Highly Significant, *p value between 0.011 and 0.050 - Significant Source: Derived from Primary data

with various CEDs. Since the results refer to standardized variables, a path coefficient $\beta$ between a variable of GSCM and a variable of CED means that, in a linear analysis, a one SD variation in the variable of CED leads to a $\beta$ SD variation in the variable of GSCM.

Indirect Effects: Based on the significant CEDs identified in the SEM, the structural equations for the path analysis to identify the indirect effect of CEDs are written as follows:

$G P=\alpha_{G P}+\beta_{G P, C u p} C u P+\beta_{G P, S C P} S c P+\beta_{G P, C o P} C o P$ $+e_{G P}$

$G M=\alpha_{G M}+\beta_{G M, R P} R P+\beta_{G M, C U P} C u P+\beta_{G M, S C P} S c P$ $+\beta_{G M, C o P} C O P+e_{G M}$

$G D=\alpha_{G D}+\beta_{G D, R P} R P+\beta_{G D, S C P} S C P+\beta_{G D, C o P} C o P$ $+e_{G D}$

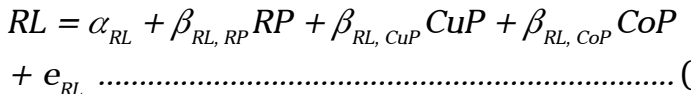

First, to determine the indirect effect of variables of CED on GSCM, the associations of the variables of CED with each other and with GSCM practices are considered. The indirect effect of one or more CEDs on GSCM practices is the product of the association of one CED on the other and the influence of that CED on the GSCM practice under consideration. The correlation coefficients of the variables used for the study are given in Table 4.

Further, by adopting a mathematical approach, the correlation between the variables of CED and GSCM are decomposed into direct and indirect effects by converting the structural equations into normal equations. For the conversion, the significant predetermined exogenous variables of equations 5,6,7,

Table 4. Correlation Coefficients of the Variables of CED and GSCM

\begin{tabular}{|c|c|c|c|c|c|c|c|c|}
\hline $\begin{array}{l}\text { Variables of CED } \\
\text { and GSCM }\end{array}$ & GP & GM & GD & RL & $\mathrm{RP}$ & $\mathrm{CuP}$ & $\mathrm{ScP}$ & $\mathrm{CoP}$ \\
\hline GP & 1.000 & $0.546 * *$ & $0.343^{* *}$ & 0.073 & $0.375 * *$ & $0.416 * *$ & $0.475 * *$ & $0.524 * *$ \\
\hline GM & $0.546 * *$ & 1.000 & $0.703 * *$ & $0.236 * *$ & $0.579 * *$ & $0.514 * *$ & $0.624 * *$ & $0.606 * *$ \\
\hline GD & $0.343^{* *}$ & $0.703 * *$ & 1.000 & $0.402^{* *}$ & $0.394 * *$ & $0.378 * *$ & $0.474 * *$ & $0.488 * *$ \\
\hline $\mathrm{RL}$ & 0.073 & $0.236 * *$ & $0.402 * *$ & 1.000 & $0.329 * *$ & $0.275^{* *}$ & $0.130 *$ & $0.203^{*}$ \\
\hline $\mathrm{RP}$ & $0.375^{* *}$ & $0.579 * *$ & $0.394 * *$ & $0.329 * *$ & 1.000 & $0.525^{* *}$ & $0.571^{* *}$ & $0.587 * *$ \\
\hline $\mathrm{CuP}$ & $0.416^{* *}$ & $0.514 * *$ & $0.378 * *$ & $0.275^{* *}$ & $0.525^{* *}$ & 1.000 & $0.436 * *$ & $0.592 * *$ \\
\hline $\mathrm{ScP}$ & $0.475^{* *}$ & $0.624 * *$ & $0.474 * *$ & $0.130 *$ & $0.571^{* *}$ & $0.436 * *$ & 1.000 & $0.621 * *$ \\
\hline $\mathrm{CoP}$ & $0.524 * *$ & $0.606^{* * *}$ & $0.488 * *$ & $0.203^{*}$ & $0.587 * *$ & $0.592 * *$ & $0.621 * *$ & 1.000 \\
\hline
\end{tabular}

**p value between 0.000 and 0.010 - Highly Significant, *p value between 0.011 and 0.050 - Significant

Source: Derived from Primary data 
and 8 are considered in turn, one after the other. The structural equations are multiplied on both the sides with the exogenous variable and expectations are taken on both the sides. For standardized variables, $\mathrm{E}\left(\mathrm{X}_{1}^{2}\right)=1$ and $\mathrm{E}\left(\mathrm{X}_{1} \mathrm{X}_{2}\right)=\Upsilon_{12}$, where, $\Upsilon_{12}$ is the expected association between $\mathrm{X}_{1}$ and $\mathrm{X}_{2}$. Hence $\Upsilon_{12}$ depicts the correlation between $\mathrm{X}_{1}$ and $\mathrm{X}_{2}$. Also, for standardized variables, it is assumed that the error in an equation is uncorrelated with any of the exogenous variables in the equation making $\mathrm{E}\left(\mathrm{eX}_{1}\right)$ $=0$, where ' $\mathrm{e}$ ' is the error term. The normalized equations obtained thus are summarized below.

$\Upsilon_{G P, C u P}=\alpha_{G P, C u P}+\beta_{G P, C u P}+\beta_{G P, S C P} \Upsilon_{S C P, C u P}$

$+\beta_{G P, C o P} \Upsilon_{C o P, C u P}$

$\Upsilon_{G P, S C P}=\alpha_{G P, S C P}+\beta_{G P, C u P} \Upsilon_{C u P, S C P}+\beta_{G P, S C P}$

$+\beta_{G P, C O P} \Upsilon_{C o P, S C P}$

$\Upsilon_{G P, C o P}=\alpha_{G P, C o P}+\beta_{G P, C u P} \Upsilon_{C u P, C o P}+\beta_{G P, S C P} \Upsilon_{S c P, C o P}$

$\Upsilon_{G M, R P}=\alpha_{G M, R P}+\beta_{G M, R P}+\beta_{G M, C u P} \Upsilon_{C U P, R P}$

$+\beta_{G M, S C P} \Upsilon_{S C P, R P}+\beta_{G M, C O P} \Upsilon_{C O P, R P}$

$\Upsilon_{G M, C u P}=\alpha_{G M, C u P}+\beta_{G M, R P} \Upsilon_{R P, C u P}+\beta_{G M, C u P}+\beta_{G M,}$

${ }_{S c P} \Upsilon_{S c P, C u P}+\beta_{G M, C o P} \Upsilon_{C o P, C u P}$
$\Upsilon_{G M, S c P}=\alpha_{G M, S c P}+\beta_{G M, R P} \Upsilon_{R P, S c P}+\beta_{G M, C u P} \Upsilon_{C u P, S C P}$

$+\beta_{G M, S C P}+\beta_{G M, C o P} \Upsilon_{C O P, S C P}$

$\Upsilon_{G M, C o P}=\alpha_{G M, C o P}+\beta_{G M, R P} \Upsilon_{R P, C o P}+\beta_{G M, C u P} \Upsilon_{C u P, C o P}$

$+\beta_{G M, S C P} \Upsilon_{S C P, C O P}+\beta_{G M, C O P}$

$\Upsilon_{G D, R P}=\alpha_{G D, R P}+\beta_{G D, R P}+\beta_{G D, S C P} \Upsilon_{S c, R P}$

$+\beta_{G D, C O P} Y_{C o P, R P}$

$\Upsilon_{G D, S C P}=\alpha_{G D, S C P}+\beta_{G D, R P} \Upsilon_{R P, S C P}+\beta_{G D, S C P}$

$+\beta_{G D, C o P} \Upsilon_{C o P, S C P}$

$\Upsilon_{G D, C O P}=\alpha_{G D, C O P}+\beta_{G D, R P} \Upsilon_{R P, C O P}+\beta_{G D, S C P} \Upsilon_{S C P, C o P}$

$+\beta_{G D, C o P}$

$\Upsilon_{R L, R P}=\alpha_{R L, R P}+\beta_{R L, R P}+\beta_{R L, C u P} \Upsilon_{C u P, R P}$

$+\beta_{R L, C o P} \Upsilon_{C o P, R P}$

$\Upsilon_{R L, C u P}=\alpha_{R L, C u P}+\beta_{R L, R P} \Upsilon_{R P, C u P}+\beta_{R L, C u P}$

$+\beta_{R L, C O P} Y_{C O P, C u P}$

$\Upsilon_{R L, C O P}=\alpha_{R L, C O P}+\beta_{R L, R P} \Upsilon_{R P, C o P}+\beta_{R L, C U P} \Upsilon_{C u P, C o P}$

$+\beta_{R L, C O P}$

By substituting the path and correlation coefficients in equations 09 to 21 , the indirect effects of the variables of CED on GSCM practices are calculated and the results are presented in Table 5 .

Table 5. Indirect Effects of the variables of CED on GSCM

\begin{tabular}{|c|c|c|c|c|c|}
\hline \multirow{2}{*}{ Significant CED } & \multirow{2}{*}{$\begin{array}{l}\text { Operating } \\
\text { Through }\end{array}$} & \multicolumn{4}{|c|}{ GSCM Practices } \\
\hline & & GP & GM & GD & $\mathrm{RL}$ \\
\hline \multirow{3}{*}{$\mathrm{RP}$} & $\mathrm{CuP}$ & - & 0.085 & - & 0.072 \\
\hline & $\mathrm{ScP}$ & - & 0.163 & 0.122 & - \\
\hline & $\mathrm{CoP}$ & - & 0.099 & 0.142 & -0.063 \\
\hline \multirow{3}{*}{$\mathrm{CuP}$} & $\mathrm{RP}$ & - & 0.135 & - & 0.124 \\
\hline & $\mathrm{ScP}$ & 0.125 & 0.125 & - & - \\
\hline & $\mathrm{CoP}$ & 0.157 & 0.100 & - & -0.064 \\
\hline \multirow{3}{*}{$\mathrm{ScP}$} & $\mathrm{RP}$ & - & 0.147 & 0.071 & - \\
\hline & $\mathrm{CuP}$ & 0.060 & 0.070 & - & - \\
\hline & $\mathrm{CoP}$ & 0.165 & 0.105 & 0.150 & - \\
\hline \multirow{3}{*}{$\mathrm{CoP}$} & $\mathrm{RP}$ & - & 0.151 & 0.073 & 0.139 \\
\hline & $\mathrm{CuP}$ & 0.082 & 0.095 & - & 0.082 \\
\hline & $\mathrm{ScP}$ & 0.178 & 0.178 & 0.133 & - \\
\hline
\end{tabular}

Source: Derived from Primary Data 
From table 5, it is observed that, apart from direct influence, CEDs also exhibit indirect influence because of their association with one or more CEDs. From table 5, the total indirect effects are calculated and the results are presented in Table 6.

From table 3 and 6 , the total effect of the variables of CED on GSCM are calculated and the same is presented in Table 7.

\section{DISCUSSION}

This research study has validated the effects of different environmental drivers on firm's green supply chain practices. The results indicate that the government regulations, customer requirements, competitor's best practices and societal image of the organisations motivate them to adopt various green supply chain practices.

Green procurement is directly impacted by customer pressure, socio-cultural pressure and competitor pressure; of which, the socio-cultural pressure $(p<0.001)$ and competitor $(p<0.001)$ pressure have higher significance on green procurement than customer pressure $(p=0.017)$. On green procurement, indirect effects are observed because of customer pressure operating through socio-cultural pressure and competitor pressure; socio-cultural pressure operating through customer pressure and competitor pressure; competitor pressure operating through customer pressure and socio-cultural pressure. The observed direct and indirect effects of CEDs on green procurement are depicted in Figure 2.

It is observed that the total indirect effect of customer pressure on green procurement is greater than the direct effect by difference in path coefficient of 0.144 . This indicates that, though not a significant direct cause on green procurement, customer pressure acts as a significant driver through sociocultural pressure and competitor pressure.

Green manufacturing is directly impacted by regulatory pressure, customer pressure, sociocultural pressure and competitor pressure. It is observed that the regulatory pressure $(p<0.001)$ and socio-cultural pressure $(\mathrm{p}<0.001)$ have

Table 6. Total Indirect Effect of the Variables of CED on GSCM

\begin{tabular}{ccccc}
\hline \multirow{2}{*}{ Variables of CED } & \multicolumn{4}{c}{ Variables of GSCM } \\
\cline { 2 - 5 } & GP & GM & GD & RL \\
\hline RP & - & 0.347 & 0.264 & 0.009 \\
\hline CuP & 0.282 & 0.360 & - & 0.060 \\
\hline ScP & 0.225 & 0.322 & 0.222 & - \\
\hline CoP & 0.259 & 0.424 & 0.206 & 0.221 \\
\hline
\end{tabular}

Source: Derived from Primary Data

Table 7. Total Effect of the Variables of CED on GSCM

\begin{tabular}{ccccc}
\hline \multirow{2}{*}{ Variables of CED } & \multicolumn{4}{c}{ Variables of GSCM } \\
\cline { 2 - 5 } & GP & GM & GD & RL \\
\hline RP & -0.011 & $0.605^{* *}$ & $0.389^{*}$ & $0.246^{* *}$ \\
\hline CuP & $0.420^{*}$ & $0.521^{* *}$ & 0.093 & $0.198^{*}$ \\
\hline ScP & $0.511^{* *}$ & $0.608^{* *}$ & $0.436^{* *}$ & -0.049 \\
\hline CoP & $0.525^{* *}$ & $0.593^{* *}$ & $0.448^{* *}$ & $0.113^{*}$ \\
\hline
\end{tabular}

**p value between 0.000 and 0.010 - Highly Significant, *p value between 0.011 and 0.050 - Significant

Source: Derived from Primary Data 


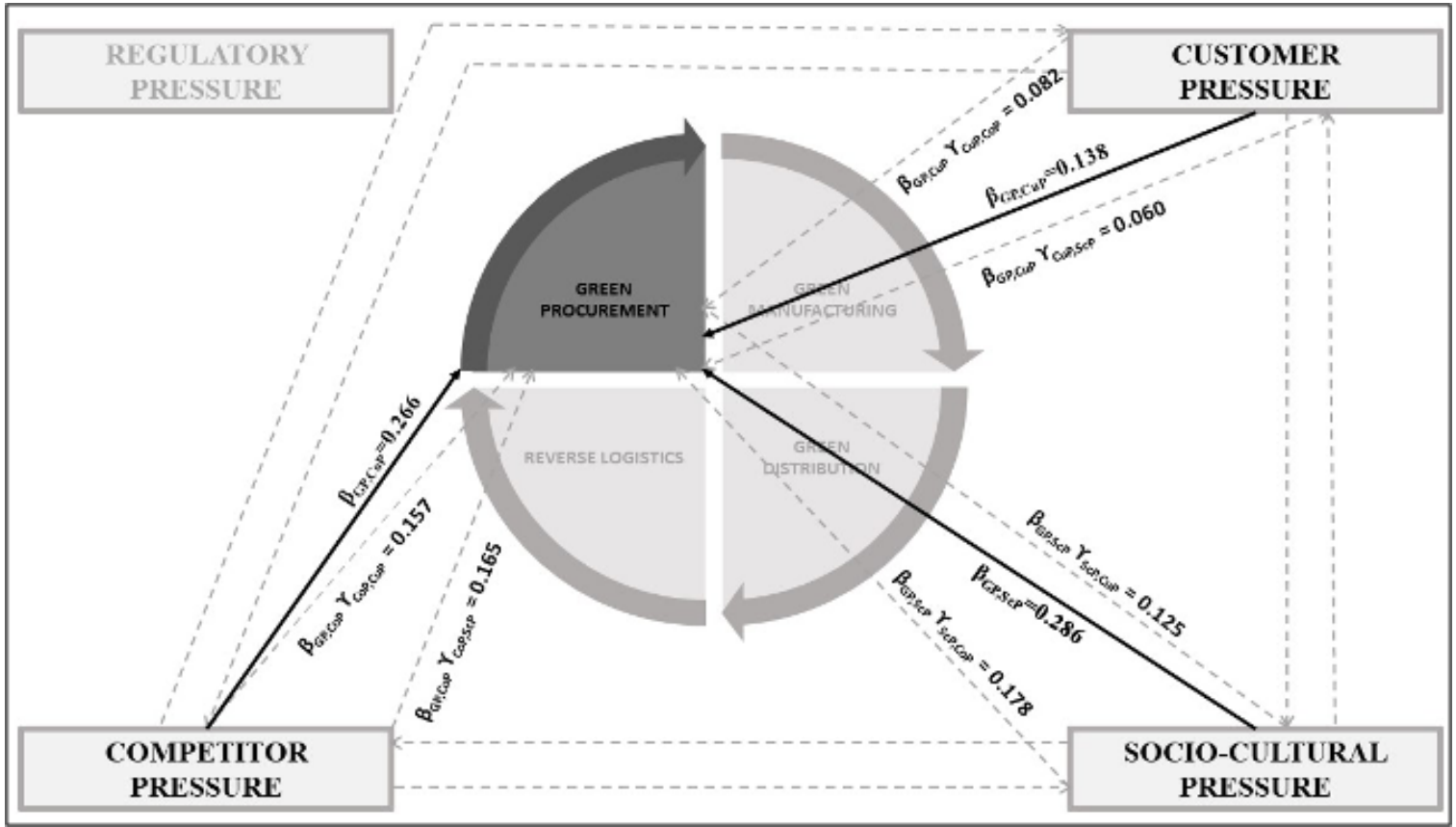

Figure 2. Observed Direct and Indirect Effects on Green Procurement Source: Self-developed

Note: In the figure, solid directed line indicates direct effect and dotted directed line indicates indirect effect

higher significance on green manufacturing than customer pressure $(\mathrm{p}=0.007)$ and competitor pressure $(p=0.005)$. On green manufacturing, indirect effects are observed because of regulatory pressure operating through customer pressure, socio-cultural pressure and competitor pressure; customer pressure operating through regulatory pressure, socio-cultural pressure and competitor pressure; socio-cultural pressure operating through regulatory pressure, customer pressure and competitor pressure; and competitor pressure operating through regulatory pressure, customer pressure and socio-cultural pressure. The observed direct and indirect effects on green manufacturing are depicted in Figure 3.

It is observed that the total indirect effects of regulatory pressure, customer pressure, sociocultural pressure and competitor pressure are greater than the direct effects by differences in path coefficients of $0.09,0.20,0.04,0.26$ respectively. This shows that the green manufacturing is impacted not just by the direct effects of CED, but greatly because of the indirect effects. It is also observed that the indirect effect of customer pressure and competitor pressure are higher than regulatory pressure and socio-cultural pressure. This shows that the lesser significant variables (customer pressure and competitor pressure) with respect to direct effect plays a crucial role in green manufacturing through their indirect effect.

Green distribution is directly impacted by regulatory pressure, socio-cultural pressure and competitor pressure; of which, the socio-cultural pressure $(p<0.001)$ and competitor pressure $(p<0.001)$ have higher significance on green distribution than that of regulatory pressure $(\mathrm{p}=0.027)$. On green distribution, indirect effects are observed because of regulatory pressure operating through socio-cultural pressure and competitor pressure; socio-cultural pressure operating through regulatory pressure and competitor pressure; competitor pressure operating through regulatory pressure and socio-cultural 


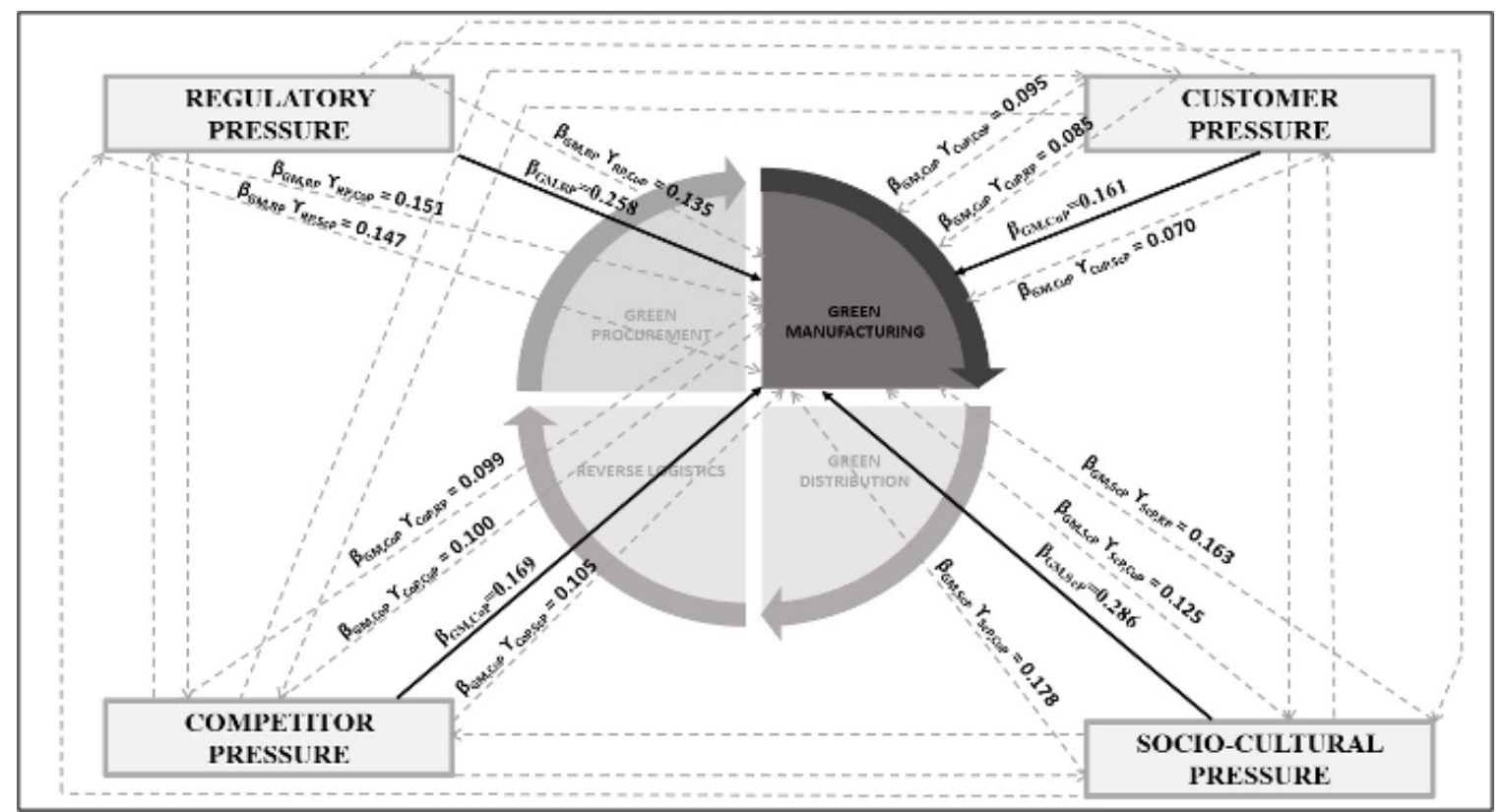

Figure 3. Observed Direct and Indirect Effects on Green Manufacturing Source: Self-developed

Note: In the figure, solid directed line indicates direct effect and dotted directed line indicates indirect effect

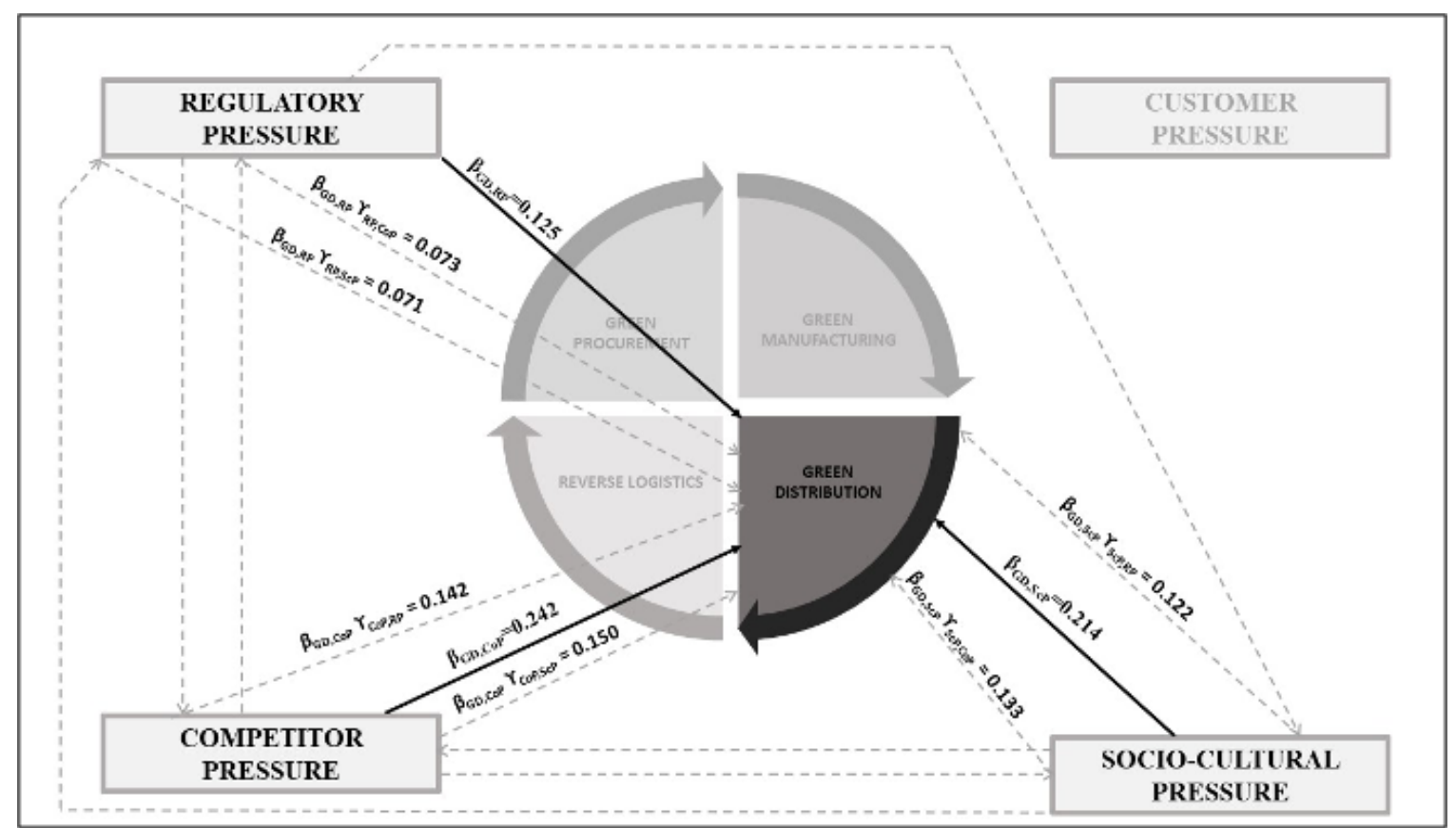

Figure 4. Observed Direct and Indirect Effects on Green Distribution Source: Self-developed

Note: In the figure, solid directed line indicates direct effect and dotted directed line indicates indirect effect

pressure. The observed direct and indirect effects on green distribution are depicted in Figure 4.
Reverse Logistics is directly impacted by regulatory pressure, customer pressure and competitor pressure; of which, the significance of regulatory 
pressure $(\mathrm{p}<0.001)$ on reverse logistics is higher than that of customer pressure $(p=0.017)$ and competitor pressure $(p=0.049)$. On reverse logistics, indirect effects are observed because of regulatory pressure operating through customer pressure and competitor pressure; customer pressure operating through regulatory pressure and competitor pressure; and competitor pressure operating through regulatory pressure and customer pressure. The observed direct and indirect effects on reverse logistics are depicted in Figure 5.

It is observed that the direct effect of competitor pressure on reverse logistics is negative but the indirect effect of competitor pressure on reverse logistics, operating through regulatory pressure and customer pressure, is positive. Indirect effect of competitor pressure on reverse logistics is greater than the direct effect by difference in path coefficient of 0.33 . This indicates that the $\mathrm{CoP}$ is also positively significant in affecting reverse logistics.

\section{CONCLUSION}

The causal modelling of the environmental drivers and green supply chain practices, taking into consideration the cumulative effects (direct and indirect effects together) through path analysis, evidently shows the permeating influence of environmental drivers on the green supply chain practices. Thus, the direct and indirect effects of environmental drivers are deeply entrenched on the green supply chain practices of Indian firms.

The study establishes that regulatory policies and compliance checks by Government authorities play an important role in adoption of green supply chain initiatives in the organisation. Regulatory pressure has direct impact on Green Manufacturing, Green Distribution and Reverse Logistics, but Green Procurement is neither directly nor indirectly impacted by Regulatory Pressure; Increased consumer interests towards green products propel the organisations towards green thinking and

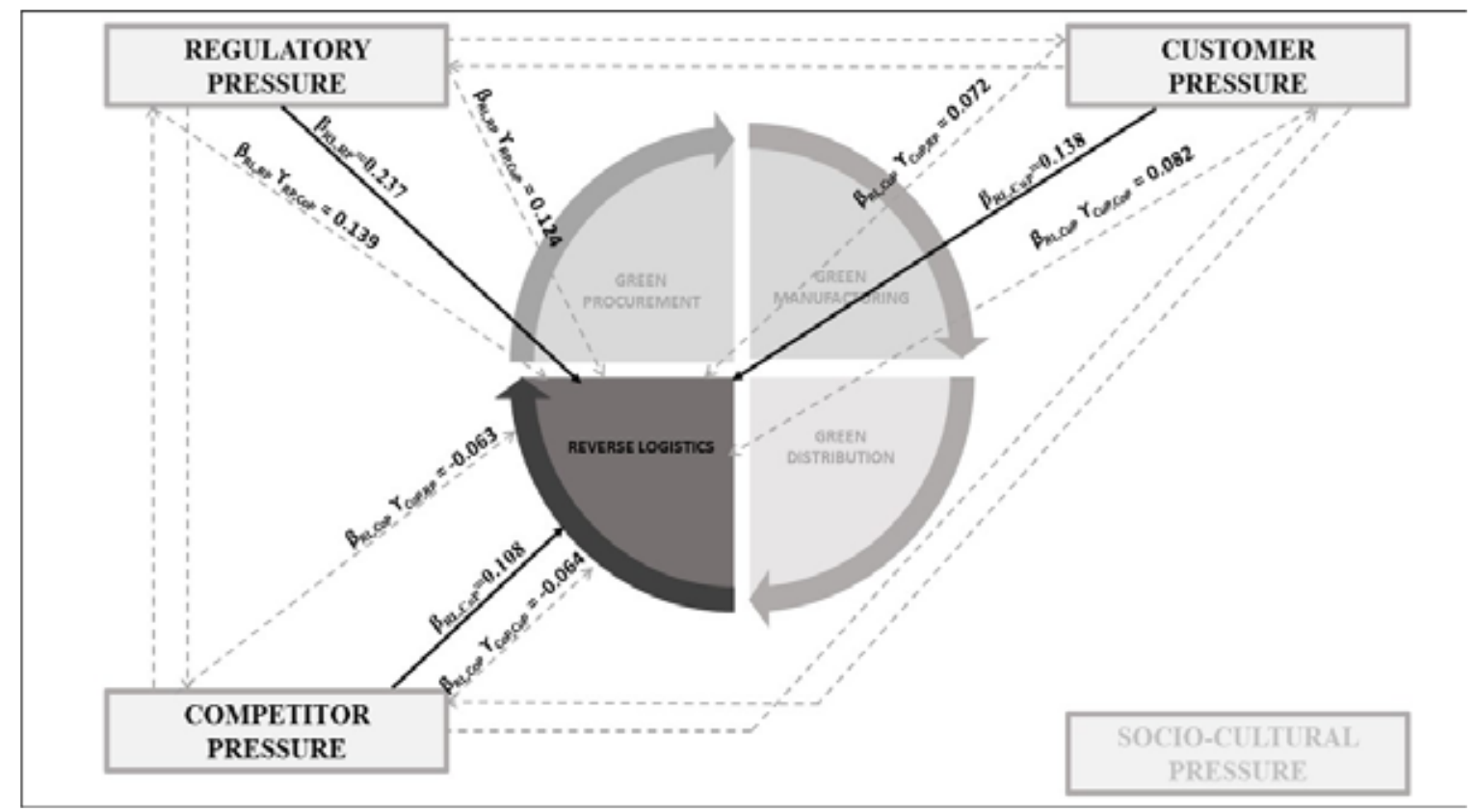

Figure 5. Observed Direct and Indirect Effects on Reverse Logistics Source: Self-developed

Note: In the figure, solid directed line indicates direct effect and dotted directed line indicates indirect effect 
impacts the supply chain practices both directly and indirectly; Success stories and best practices of the competitors' green policies drive the green supply chain practices of the firms under study.

\section{MANAGERIAL IMPLICATIONS}

The direct impact of competitor pressure is significantly higher on Green Procurement and Green Distribution than on Green Manufacturing and Reverse Logistics and the indirect impact of Competitor Pressure on Green Manufacturing is found to be significant because of its strong association with Regulatory Pressure, Customer Pressure, and Socio-Cultural Pressure. Sociocultural pressure shows direct significant influence on the supply chain practices of the organisations, to display their responsible behavior with respect to the impact of their activities on the environment and set the right organisational image in the society. Thus, the direct and indirect effects of
CEDs on GSCM help manage green practices in the organisations. The result of this study invites necessary attention of the managers to undertake an analysis on the effects of potential environmental drivers in their respective firms and be conscious of the effects of CEDS that are observed during the implementation of GSCM practices.

\section{Limitations And Scope For Further Research}

The main limitation of the study is the limited geographic span and industry type chosen. Further research may replicate the study in other geographic areas and may include a variety of industries to enhance the generalizability of the results. This study has concentrated only on the coercive pressures on GSCM practices, thus, leaving a scope to include non-coercive pressures in the further study. It is also recommended that analysis based on contextual variables may be included in further studies.

REFERENCES

Bag, S. (2013). Designing the Green Supply Chain Strategy for Indian Manufacturing Firm. Journal of Supply Chain Management Systems, 2(1), 8-18.

Beyea, S. C. (2005). High reliability theory and highly reliable organizations. AORN Journal, 81(6), 1319-1322.

Caddy, I. N., \& Helou, M. M. (2007). Supply chains and their management: Application of general systems theory. Journal of Retailing and Consumer Services, 14(5), 319-327.

Cai, N. N. (2012). On the Feasibility of Green Packaging from the Use of Bamboo. Advanced Materials Research, 591-593, $40-43$.

Check-Teck, F. (2010). Exploring thinking from antiquity in managing logistics, supply and resources: Chinese Sun Tzu, Indian Kautilya and supply chain management. International Journal of Indian Culture and Business Management, 3(2), pp.121137.

Colwell, S. R., \& Joshi, A. W. (2009). Multi-Item Scale Development for Measuring Institutional Pressures in the Context of Corporate Environmental Action. Proceedings of the International Association for Business and Society, 20, 146-152.

Dhull, S., \& Narwal, M. S. (2016). Drivers and barriers in green supply chain management adaptation: A state-of-art review. Uncertain Supply Chain Management, 61-76.

Diabat, A., \& Govindan, K. (2011). An analysis of the drivers affecting the implementation of green supply chain management. Resources, Conservation and Recycling, 55(6), 659-667. 
Diabat, A., Kannan, D., \& Mathiyazhagan, K. (2014). Analysis of enablers for implementation of sustainable supply chain management - A textile case. Journal of Cleaner Production, 83, 391-403.

Edser, C. (2009). Eco-labels and sustainability. Focus on Surfactants, 2009(7), 1-2.

Faisal, M. (2015). Research Analysis on Barriers to Green Supply Chain Management in Pharmaceutical Industries. Review of Public Administration and Management, 03(01).

Fox, R., Thorson, P., Horst, B., Speros, J., Rothermich, N., \& Hatayama, H. (2009). Environmental Management System Plan. https://doi.org/10.2172/951107

Fu, Q., Liu, Q., Zhong, S., Luo, H., Wu, H., \& Chen, J. (2018). Single Trajectory Learning: Exploration Versus Exploitation. International Journal of Pattern Recognition and Artificial Intelligence, 32(06), 185-909.

Gerlagh, R., \& Liski, M. (2011). Strategic resource dependence. Journal of Economic Theory, 146(2), 699-727.

Gunningham, N. (2009). Shaping corporate environmental performance: a review. Environmental Policy and Governance, $19(4), 215-231$.

Huang, Y., \& Chu, W. (2010). Enhancement of product development capabilities of OEM suppliers: inter-and intra-organisational learning. Journal of Business \& Industrial Marketing, 25(2), 147-158.

Khare, A., \& Khare, A. (2010). Challenges and perspectives of supply chain collaborations in the Indian automobile sector. International Journal of Indian Culture and Business Management, 3(2), 138-161.

Lintukangas, K., Hallikas, J., \& Kähkönen, A. (2015). The Role of Green Supply Management in the Development of Sustainable Supply Chain. Corporate Social Responsibility and Environmental Management, 22(6), 321-333.

Martí, J. M. C., \& Seifert, R. W. (2013). Assessing the Comprehensiveness of Supply Chain Environmental Strategies. Business Strategy and the Environment, 22(5), 339-356.

Mathiyazhagan, K., Govindan, K., \& Haq, A. N. (2013). Pressure analysis for green supply chain management implementation in Indian industries using analytic hierarchy process. International Journal of Production Research, 52(1), 188-202.

Miler-Virc, A., \& Glusica, Z. (2012). ENVIRONMENTAL MANAGEMENT SYSTEMS CERTIFICATION. Journal of Economic Development, Environment and People, 1(3), 22-31.

Morana, J., \& Morana, J. (2013). The Environmental Aspect of Sustainable Supply Chain Management (pp. 53-106).

Morgan, T. R., Jr, R. G. R., \& Autry, C. W. (2016). Developing a reverse logistics competency. International Journal of Physical Distribution \& Logistics Management, 46(3), 293-315.

Onozaka, Y., Hu, W., \& Thilmany, D. D. (2015). Can eco-labels reduce carbon emissions? Market-wide analysis of carbon labeling and locally grown fresh apples. Renewable Agriculture and Food Systems, 31(2), 122-138.

Ouyang, H. Z. (2014). Application of Green Packaging Material with a Necessary Analysis on the Packaging Design. Advanced Materials Research, 977, 112-115.

Pozo, H., Akabane, G. K., Galhardi, A. C., \& Peterossi, H. G. (2015). Sustainability As A Success Factor In Global Operations: A Survey Of Car Manufacturing Supply Chains. Independent Journal of Management \& Production, 6(2), 525-547.

Preuss, L. (2005). Rhetoric and Reality of Corporate Greening: A View from SCM Fucntion. Business Strategy and the Environment, 14(2), 123-139.

Raak, A. van, Rijk, A. de, \& Morsa, J. (2005). Applying new institutional theory. Work, Employment and Society, 19(1), 141-151.

Rao, P., \& Holt, D. (2005). Do green supply chains lead to competitiveness and economic performance? International Journal of Operations \& Production Management, 25(9), 898-916.

Rauer, J., \& Kaufmann, L. (2014). Mitigating External Barriers to Implementing Green Supply Chain Management: A Grounded Theory Investigation of Green-Tech Companies' Rare Earth Metals Supply Chains. Journal of Supply Chain Management, 40.

Sarkis, J. (2012). A boundaries and flows perspective of green supply chain management. Supply Chain Management: An International Journal, Volume 17(Issue 2), 202-216.

Setthasakko, W. (2009). Barriers to implementing corporate environmental responsibility in Thailand. International Journal of Organizational Analysis, 17(3), 169-183. https://doi.org/10.1108/19348830910974905

Shah, K. U. (2011). Strategic organizational drivers of corporate environmental responsibility in the Caribbean hotel industry. Policy Sciences, 44(4), 321

Sharma, S. (2001). Different strokes: regulatory styles and environmental strategy in the North $\square$ American oil and gas industry. Business Strategy and the Environment, 10(6), 344-364.

Sharma, S., \& Gandhi, M. A. (2016). Exploring correlations in components of green supply chain practices and green supply chain performance. Competitiveness Review, Volume 26(Issue 3), 332-368.

Srivastava, S. K. (2004). Reverse Logistics. Vikalpa, 29(4), 161-166.

Suddaby, R. (2010). Challenges for Institutional Theory. Journal of Management Inquiry, 19(1), 14-20.

Swami, S, \& Shah, J. (2013). Channel coordination in green supply chain management. Journal of the Operational Research Society, 64(3), 336-351 
Swami, Sanjeev, \& Shah, J. (2011). Channel Coordination in Green Supply Chain Management: The Case of Package Size and Shelf-Space Allocation. Technology Operation Management, 2(1), 50-59.

Tachizawa, E. M., Gimenez, C., \& Sierra, V. (2015). Green supply chain management approaches: drivers and performance implications. International Journal of Operations \& Production Management, 35(11), 1546-1566.

Verma, D., Dixit, R. V., \& Singh, K. (2018). Green Supply Chain Management: A Necessity for Sustainable Development. The IUP Journal of Management, 15(1), 40-58.

Vivek, N., Ravindran, S., Shalij, P.R. and Devadasan, S.R. (2009). Impact of information quality on the organisational performance in supply chain environment-an empirical study in India. International Journal of Indian Culture and Business Management, 2(2), pp.111-124.

Walker, D., Pitt, M., \& Thakur, U. J. (2007). Environmental management systems. Journal of Facilities Management, 5(1), 49-61.

Walker, H., Sisto, L. D., \& McBain, D. (2008). Drivers and barriers to environmental supply chain management practices: Lessons from the public and private sectors. Journal of Purchasing and Supply Management, 14(1), 69-85.

Xu, L., Mathiyazhagan, K., Govindan, K., Haq, A. N., Ramachandran, N. V., \& Ashokkumar, A. (2013). Multiple comparative studies of Green Supply Chain Management: Pressures analysis. Resources, Conservation and Recycling, 78, $26-35$.

Zhu, Q., Geng, Y., \& Lai, K. (2010). Circular economy practices among Chinese manufacturers varying in environmentaloriented supply chain cooperation and the performance implications. Journal of Environmental Management, 91(6), 1324-1331.

Zhu, Q., Sarkis, J., \& Geng, Y. (2005). Green supply chain management in China: pressures, practices and performance. International Journal of Operations \& Production Management, Volume 25(Issue 5), 449-468. 